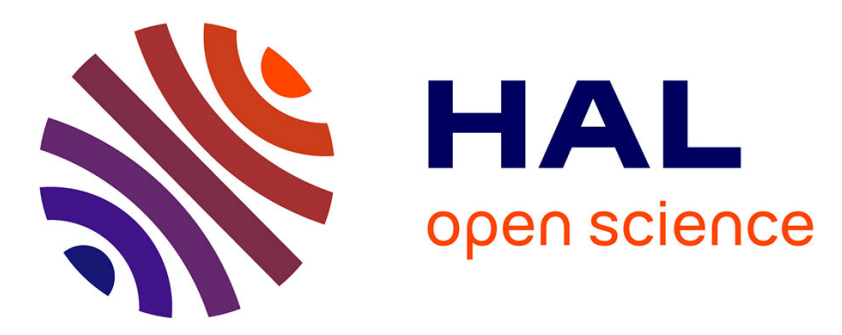

\title{
Does the invasive plant Elymus athericus modify fish diet in tidal salt marshes?
}

Pascal Laffaille, Julien Pétillon, Emmanuel Parlier, Loïc Valery, Frédéric Ysnel, Alain Radureau, Eric Feunteun, Jean-Claude Lefeuvre

\section{To cite this version:}

Pascal Laffaille, Julien Pétillon, Emmanuel Parlier, Loïc Valery, Frédéric Ysnel, et al.. Does the invasive plant Elymus athericus modify fish diet in tidal salt marshes?. Estuarine, Coastal and Shelf Science, 2005, 65, pp. 739-746. 10.1016/j.ecss.2005.07.023 . hal-00793408

\section{HAL Id: hal-00793408 https://hal.science/hal-00793408}

Submitted on 22 Feb 2013

HAL is a multi-disciplinary open access archive for the deposit and dissemination of scientific research documents, whether they are published or not. The documents may come from teaching and research institutions in France or abroad, or from public or private research centers.
L'archive ouverte pluridisciplinaire HAL, est destinée au dépôt et à la diffusion de documents scientifiques de niveau recherche, publiés ou non, émanant des établissements d'enseignement et de recherche français ou étrangers, des laboratoires publics ou privés. 


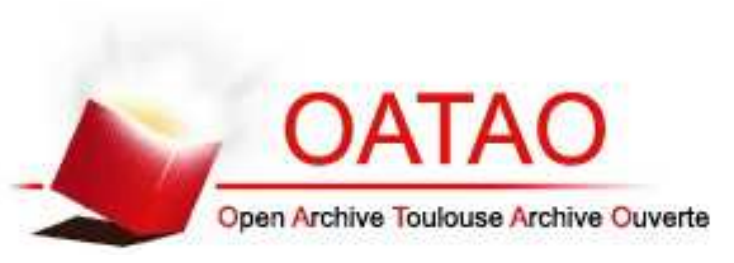

\section{Open Archive Toulouse Archive Ouverte (OATAO)}

OATAO is an open access repository that collects the work of Toulouse researchers and makes it freely available over the web where possible.

This is an author-deposited version published in: http://oatao.univ-toulouse.fr/ Eprints ID: 6193

To link to this article: DOI: 10.1016/j.ecss.2005.07.023

URL: http://dx.doi.org/10.1016/j.ecss.2005.07.023

To cite this version: Laffaille, Pascal and Pétillon, Julien and Parlier, Emmanuel and Valéry, Loïc and Ysnel, Frédéric and Radureau, Alain and Feunteun, Eric and Lefeuvre, Jean-Claude Does the invasive plant Elymus athericus modify fish diet in tidal salt marshes? (2005) Estuarine, Coastal and Shelf Science, Vol. 65 ( ${ }^{\circ}$ 4). pp. 739-746. ISSN 0272-7714

Any correspondence concerning this service should be sent to the repository administrator: staff-oatao@ listes-diff.inp-toulouse.fr 


\title{
Does the invasive plant Elymus athericus modify fish diet in tidal salt marshes?
}

\author{
P. Laffaille ${ }^{\mathrm{a}, \mathrm{b}, 1, *}$, J. Pétillon $^{\mathrm{a}, 1}$, E. Parlier ${ }^{\mathrm{a}, 1,2}$, L. Valéry $^{\mathrm{a}}, \mathrm{F}$. Ysnel ${ }^{\mathrm{a}}$, \\ A. Radureau ${ }^{a}$, E. Feunteun ${ }^{\mathrm{a}, 2}$, J.-C. Lefeuvre $^{\mathrm{a}}$ \\ "Equipe de Recherche Technologique 52 "Biodiversité Fonctionnelle et Gestion des Territoires", Campus de Beaulieu, \\ Université de Rennes 1, 35042 Rennes cedex, France \\ ${ }^{\mathrm{b}}$ Fish-Pass, 8 allée de Guerlédan, ZA Parc rocade sud, 35135 Chantepie, France
}

\begin{abstract}
The invasion of Mont-Saint-Michel Bay salt marshes (France) by a grass species (Elymus athericus) has led to important changes in vegetation cover, which is likely to modify the habitat for many invertebrates. Some of them constitute the main food items for several fish species, such as young sea bass (Dicentrarchus labrax) and sand goby (Pomatoschistus minutus), that feed in salt marsh creeks during high tides. As a result, fish nursery functions of salt marshes could be modified by the E. athericus invasion. In order to test this hypothesis, gut contents of the two most abundant fish species (sea bass and sand goby) were compared before and after E. athericus invasion in the same salt marsh creek and using the same methodology. The accessibility and availability of the main food item, the semi-terrestrial amphipod Orchestia gammarella, were estimated and compared between invaded (dominated by E. athericus) and original areas (dominated by Atriplex portulacoides). Gut content analysis showed a significantly greater percentage of fish leaving with empty guts from E. athericus areas than from A. portulacoides areas. The sea bass diet composition study showed a major shift in the relative importance of the main food items: before $E$. athericus invasion, diets were dominated by the semi-terrestrial species $O$. gammarella, whereas after the $E$. athericus invasion they were dominated by a marine mysid Neomysis integer. The same trend was found for sand gobies, with a shift of the main food item from O. gammarella before invasion to the polychaete Hediste diversicolor after invasion. These trophic changes may be explained by the lower accessibility and availability of $O$. gammarella in invaded communities than in natural ones. The E. athericus invasion, observed throughout northern Europe, is thus likely to disturb trophic function of natural salt marshes for fish. This preliminary study of the E. athericus invasion is also an illustration that invasive species are an urgent problem in conservation biology.
\end{abstract}

Keywords: invasive species; fish nursery; food resources; salt marsh function; Amphipoda

\section{Introduction}

Salt marshes are complex ecotones between terrestrial and marine systems and are among the most productive systems of

\footnotetext{
* Corresponding author.

E-mail address: plaffaille@ hotmail.com (P. Laffaille).

1 All these authors contributed equally to the work.

2 Present address: Laboratoire de Biologie et de l'Environnement Marin, Université de la Rochelle, Avenue Michel Crépeau, 17042 La Rochelle cedex, France.
}

the biosphere (Lefeuvre et al., 2000). Since the introduction of the outwelling concept (Odum, 1968), which states that tidal events export detrital organic matter produced in salt marshes to marine waters, strong evidence has also indicated that the export of organic matter from terrestrial to aquatic systems supports secondary production (Loneragan et al., 1997; Kurata et al., 2001). Consequently, salt marshes generally have a very high conservation value, directly as a result of their species complement and because of their role as a feeding ground for migrant birds (Norris et al., 1997; Lefeuvre et al., 2000), 
and fish, especially juveniles (Boesch and Turner, 1984; Laffaille et al., 2001, 2002).

Thirty fish species colonize and forage in the salt marshes of the Mont-Saint-Michel Bay (France) during the flood tide (Laffaille et al., 2000a). The habitats of the intertidal salt marshes of the Mont-Saint-Michel Bay are highly suitable for an abundant fish community. Marine straggler species (Clupeidae, Gadidae, etc.) are infrequently found. Marine estuarine dependent species (Mugilidae, Serranidae, Pleuronectidae, etc.) and estuarine species (Gobiidae, etc.) are more abundant and dominate the fish community, especially Pomatoschistus spp., Liza spp. and Dicentrarchus labrax L. Anadromous and catadromous species (especially the European eel, Anguilla anguilla L.) migrate between the marine and freshwater environment and colonize salt marshes and reclaimed marshes (Laffaille et al., 2004). In contrast, freshwater species (Cyprinidae, Esocidae, etc.) are infrequent and generally die rapidly in this environment where abiotic conditions (salinity, temperature, turbidity, etc.) change rapidly.

During high tide, young sea bass (Dicentrarchus labrax L.) and sand gobies (Pomatoschistus minutus Pallas) exploit salt marsh production by feeding on resident invertebrates, mainly Orchestia gammarella (Laffaille et al., 1999, 2001). Pomatoschistus minutus is among the most abundant fish species of coastal waters of western Europe (Costa and Cabral, 1999), and occurs frequently at high densities in a large European intertidal salt marsh (Laffaille et al., 2000a; Salgado et al., 2004). The sand goby is an important prey for fish-eating vertebrates (Moreira et al., 1992; Hamerlynck and Cattrijsse, 1994). Dicentrarchus labrax is one of the most abundant commercial species of the Atlantic coast and in the Mont-Saint-Michel Bay (Laffaille et al., 2000a), where young fish, especially young of the year $(0+)$, exploit tidal salt marshes (Laffaille et al., 2001).

The present research team has surveyed the progression and transformation processes of the Mont-Saint-Michel Bay salt marshes since 1984 when the first vegetation map was produced (Bouchard et al., 1995; Valéry et al., 2004). This long-term survey has highlighted radical changes of the vegetation cover in the salt marsh due to a rapid invasion by Elymus athericus (=Elytrigia atherica). Formerly confined to the high marsh, this native species is progressively invading the middle and low salt marshes where it often forms a dense monospecific stand (Van Wijnen and Bakker, 1997; Bockelmann and Neuhaus, 1999; Bouchard et al., 2003). In some areas of the Mont-SaintMichel Bay, this species has progressively extended its area threefold in only 10 years and has replaced the middle marsh Atriplex portulacoides communities (Valéry et al., 2004). During the past 10 years, E. athericus has spread at a rate of

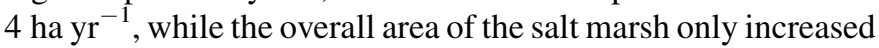
by $1.5 \mathrm{ha} \mathrm{yr}^{-1}$. The percent of marsh occupied by this species has increased from 37\% to $73 \%$ between 1991 and 2001 (Valéry et al., 2004). Although this species spread along creeks in 1991 (i.e. it was exclusively distributed along the banks of drainage creeks), its distribution in 2001 was no longer limited to the channel creeks but was filling in between the creeks network. The increase of salt marsh area occupied by E. athericus occurred to the detriment of $A$. portulacoides, which covered nearly $1 / 3$ of the marsh in 1991 (Bouchard et al., 1995) but only $1 / 8$ of the marsh in 2001 (Valéry et al., 2004).

Such a progression is characteristic of invasive species (Cronk and Fuller, 2001), common in European salt marshes (Bockelmann and Neuhaus, 1999). Biological invasions are ongoing worldwide and have become recognized as a major factor resulting in ecosystem process changes (Vitousek et al., 1987; Kourtev et al., 2002). Invasive species decrease the functional biodiversity, which could explain their impact on ecosystem functions such as primary productivity (Naeem et al., 1996; Tilman et al., 1996), organic nutrient matter cycles (Hooper and Vitousek, 1997; Valéry et al., 2004), hydrology and pedogenesis (Vitousek, 1990). In coastal areas, ecological functioning might be disturbed by Elymus athericus, in particular because the organic matter flux processes between salt marshes and coastal waters may be modified and the whole or part of the food web might also be unbalanced. Several functions of the salt marshes may therefore be modified by such an invasion: the export capacity of the salt marsh could be modified and in turn could affect mussel and oyster culture with resulting economic effects; the habitat value for Anatidae and other game birds could be changed (Lefeuvre et al., 2003; Valéry et al., 2004). The role of invasive plants on the alteration of trophic function for larvae and juveniles of fish and crustaceans has been studied along the North American Atlantic coast with common reed Phragmites australis (see for example Able and Hagan, 2000; Wainright et al., 2000; Hanson et al., 2002). In comparison, the effects of E. athericus on trophic function for European fish have rarely been studied, although European salt marshes play important roles for fish communities.

The aim of this study is to examine the impact of Elymus athericus on trophic function for fish communities, one of the connotations of the nursery concept (Beck et al., 2001). Because natural salt marshes dominated by Atriplex portulacoides are highly productive and provide large quantities of organic matter (from 1080 to $1990 \mathrm{~g}$ dry weight of net aerial primary production $\mathrm{m}^{-2} \mathrm{yr}^{-1}$ ), they provide habitat refuges and food resources to sustain high densities of Orchestia gammarella (Lefeuvre et al., 2000). It is therefore hypothesized that the new habitat created by E. athericus is likely to reduce food resources for young fish during high tides and to disturb salt marsh trophic and consequently nursery functions. To test this, the feeding and diet of Dicentrarchus labrax (sea bass) and Pomatoschistus minutus (sand goby) were compared in salt marshes of the Mont-SaintMichel Bay before and after E. athericus invasion. In order to study the effects of Elymus on fish food resources, accessibility and availability of their main food item in natural salt marshes between invaded and natural plots were also compared.

\section{Material and methods}

\subsection{Study site}

The Mont-Saint-Michel Bay (France) is a wide littoral zone located in the Norman-Breton Gulf (latitude $48^{\circ} 40^{\prime} \mathrm{N}$, longitude $1^{\circ} 35^{\prime} \mathrm{W}$ ) extending over $500 \mathrm{~km}^{2}$ (Fig. 1). This area is a macrotidal system characterized by a high tidal range 


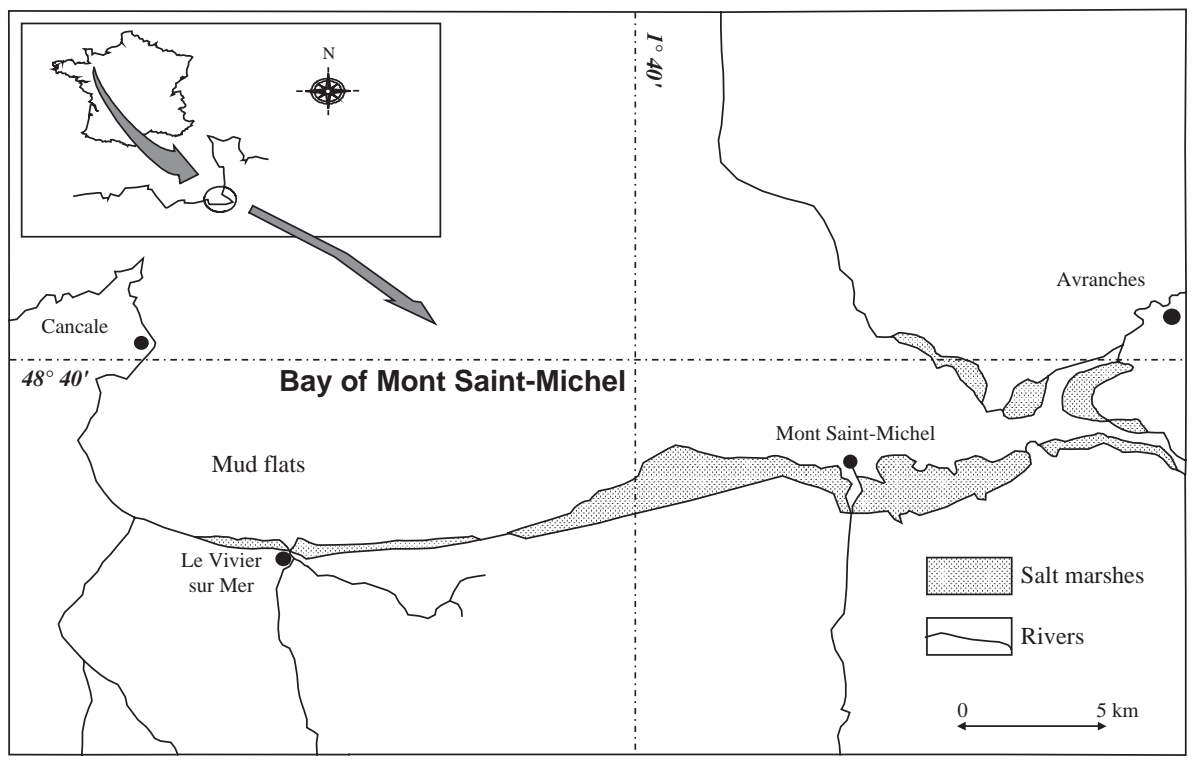

Fig. 1. Location of the Mont-Saint-Michel Bay.

(mean tidal range $=10-11 \mathrm{~m}$, maximum $=16 \mathrm{~m})$. The intertidal area covers $220 \mathrm{~km}^{2}$ and contains $180 \mathrm{~km}^{2}$ of mud and sand flats and $40 \mathrm{~km}^{2}$ of salt marshes. Salt marshes are drained by a dense creek system (Lefeuvre et al., 2000) and are flooded during $43 \%$ of tides when the tidal range is greater than $11.25 \mathrm{~m}$. Flooding lasts on average $2 \mathrm{~h}$ per tide. The rest of the time the salt marsh, including tidal creeks and vegetated tidal flats, is emerged. Thus, this complex is colonized by fish and marine-estuarine invertebrates such as mysids, amphipods and decapods only for very short periods $(1-2 \mathrm{~h})$ during the spring tides when the vegetated creeks and the vegetated intertidal surface are accessible (Laffaille et al., 1998, 2000a). Other macro-invertebrates are semi-terrestrial (e.g. the amphipod Orchestia gammarella) or adapted to the submersion-inundation cycles such as the polychaete Hediste diversicolor. These invertebrates are resident in salt marshes.

\subsection{Fish sampling}

Sea bass and sand gobies were, respectively, caught in 1997 and 1998 before the Elymus athericus invasion in one salt marsh creek (Laffaille et al., 1999, 2001) and in 2002 in the same salt marsh creek after E. athericus invasion. During this period, only the vegetation has changed; the tidal hydrology (flooding frequency and duration), the water chemistry (temperature, conductivity, nitrate, phosphate, salinity, etc.), altitudinal ranges and the climatic conditions are the same. The epifaunal composition was almost the same in Atriplex portulacoides vegetation in 1986 and in 2004, except for some very mobile arthropods (e.g. cursorial spiders) that tended to enter natural areas from the invaded surroundings (Pétillon et al., 2005).

The study creek is situated $2.5 \mathrm{~km}$ from the coastline on a $10 \mathrm{~m}$ wide creek, which drains a 5.7 ha watershed. Fish were caught monthly from spring (recruitment period in the bay) to autumn when sea bass and sand gobies colonized intertidal marshes with maximum abundances in the Mont-Saint-Michel
Bay. A minimum of eight samples were collected each year. Each month, one or two samples were collected (if the first fish sample size was small) in spring time. Samplings were made during the evening ebb in order to analyse diet composition after residence in salt marsh creeks (Laffaille et al., 1999, 2001). Samplings were conducted using $4 \mathrm{~mm}$ mesh fyke nets set across the creek (see Laffaille et al., 1998). All samples were stored immediately in a refrigerated box (about $0{ }^{\circ} \mathrm{C}$ ) in salt marsh and in a deep freezer $\left(-18^{\circ} \mathrm{C}\right)$ at the laboratory until examination of the gut contents. The time between sample collection and deposition was about $2-3 \mathrm{~h}$. Fish were individually measured to the nearest $\mathrm{mm}$ [fork length (FL) for sea bass and total length (TL) for goby].

\subsection{Gut content analysis}

The entire digestive tract was removed from each fish. The number of empty stomachs was counted, and a vacuity index ( $V$, proportion of empty stomachs) was determined as an index of feeding intensity. $V$ was compared using a Chi-square test with Yates correction.

Prey items were identified for each fish species and were weighed to the nearest $1 \mathrm{mg}$. For each sample, the percentage of occurrence $\left(F_{i}\right.$, percentage of full stomachs where prey $i$ was present), the percentage abundance $\left(N_{i}\right.$, numerical percentage of prey $i$ in the food item community) and the biomass composition $\left(B_{i}\right.$, biomass percentage of prey $i$ in the food item community) were calculated. In order to analyse and compare the diets at the population level, the Main Food Index (MFI) modified by Laffaille et al. (1999) was used for each food item $i$ :

$\mathrm{MFI}_{i}=\left[\left(\left[B_{i}\left(N_{i}+F_{i}\right) / 2\right]^{1 / 2}\right) /\left(\sum(\mathrm{MFI})\right)\right] \times 100$

MFI were compared using a $G$ test or likelihood ratio test as modified by Williams (1976). 


\subsection{Orchestia gammarella availabilities and accessibilities}

Both availability and accessibility of the main food item were estimated and compared between habitats invaded by Elymus athericus and the natural habitat of middle salt marshes (i.e. Atriplex portulacoides communities). The invaded and uninvaded areas had similar altitudinal ranges. The availability of Orchestia gammarella was estimated by density (number $\mathrm{m}^{-2}$ ) measurements using a depletion method. Within each plant community, four $1 \mathrm{~m}^{2}$ quadrats were randomly installed and sampled by hand catches and pitfall traps until there were no more individuals. Final hand collections were carried out to collect potential remaining individuals. Previous studies showed the need for 10 sampling days to empty a quadrat (Pétillon et al., unpublished data). All densities were corrected according to the vertical distribution of $O$. gammarella (estimated by vertical soil samplings, 1 per quadrat). The procedure was carried out three times during summer 2003.

The accessibility of Orchestia gammarella was estimated by abundance measurements (number day ${ }^{-1}$ trap $^{-1}$ ). Orchestia gammarella abundances were sampled by pitfall traps (circular plastic, $10 \mathrm{~cm}$ in diameter, $17 \mathrm{~cm}$ depth and ethyleneglycol for preservative) in the two vegetation groups studied, i.e. Atriplex portulacoides and Elymus athericus communities. The number of animals caught depends on both population size and activity (Greenslade, 1964) and pitfall traps provide an estimation of accessibility of this invertebrate (moving individuals) to fish species.

In order to characterize the habitat formed by each plant community, the following parameters were measured within a radius of $1 \mathrm{~m}$ around each pitfall trap: litter depth and vegetation height of each plant species.

All measurements were compared using unpaired $t$ test with Welch's correction. This test does not assume similar variances. However, this test assumes that data are sampled from populations that have a normal distribution. This assumption was tested using Kolmogorov-Smirnov's method (Lillefors option).

\section{Results}

\subsection{Sea bass diet}

A total of 792 sea bass (mean LF $\pm \mathrm{sd}=32.2 \pm 8.5 \mathrm{~mm}$, range between 18 and $67 \mathrm{~mm}$ ) were analysed in 1997-1998; 121 sea bass (mean $\mathrm{LF} \pm \mathrm{sd}=28.2 \pm 5.5 \mathrm{~mm}$, range between 19 and $43 \mathrm{~mm}$ ) were caught and analysed in 2002 . Differences of vacuity index were very significant before (1997-1998) and after (2002) Elymus invasion $\left(\chi^{2}=\right.$ 139.57, $p<0.0001)$ : generally very few sea bass had empty stomachs (mean $V=1.4 \%$ ) when fish left salt marshes during ebb in 1997-1998, whereas $25.5 \%$ of sampled fish in 2002 had empty stomachs. There was no significant difference between 1997 and 1998 before Elymus invasion $\left(\chi^{2}=19.7, p>0.75\right)$.

Before Elymus invasion, the main food item of sea bass was Orchestia gammarella (mean MFI $=64 \%$ ), which occurred in $79 \%$ of the stomachs (Table 1). This amphipod dominated the
Table 1

Food items identified in the stomach contents of young sea bass caught during ebb in 1997-1998 and in 2002. $N$ : numeric frequency. $B$ : biomass frequency. $F$ : frequency of occurrence. MFI: main food index

\begin{tabular}{|c|c|c|c|c|c|c|c|c|}
\hline & \multicolumn{4}{|c|}{ 1997-1998 } & \multicolumn{4}{|l|}{2002} \\
\hline & $N$ & $F$ & $B$ & MFI & $N$ & $F$ & $B$ & MFI \\
\hline \multicolumn{9}{|l|}{ Fishes } \\
\hline Pomatoschistus sp. & 0.0 & 0.4 & 0.1 & 0.1 & - & - & - & - \\
\hline \multicolumn{9}{|l|}{ Insects } \\
\hline Culicidae larvae & 0.5 & 1.6 & 0.1 & 0.3 & 1.2 & 3.8 & 0.0 & 0.2 \\
\hline Arachnids & 0.3 & 1.4 & 0.4 & 0.6 & - & - & - & - \\
\hline \multicolumn{9}{|l|}{ Crustacean } \\
\hline Crangon crangon & 0.1 & 0.4 & 0.5 & 0.3 & - & - & - & - \\
\hline Palaemonetes varians & 0.3 & 3.0 & 1.4 & 1.4 & - & - & - & - \\
\hline Carcinus maenas & 0.4 & 2.4 & 1.5 & 1.3 & - & - & - & - \\
\hline Orchestia gammarellus & 58.2 & 78.9 & 72.9 & 63.9 & 28.2 & 22.8 & 39.8 & 32.2 \\
\hline Corophium volutator & 6.3 & 16.1 & 1.6 & 3.8 & - & - & - & - \\
\hline Bathyporeia sp. & 0.4 & 0.2 & 0.1 & 0.2 & - & - & - & - \\
\hline Sphaeroma rugicauda & 0.3 & 0.7 & 0.8 & 0.6 & - & - & - & - \\
\hline Eurydice pulchra & 8.5 & 12.1 & 2.3 & 4.4 & - & - & - & - \\
\hline Neomysis integer & 14.2 & 28.5 & 8.0 & 11.9 & 49.8 & 81.0 & 56.3 & 61.3 \\
\hline Copepodites & 8.6 & 7.2 & 2.7 & 4.2 & 14.3 & 6.3 & 0.4 & 2.1 \\
\hline Undetermined & 0.0 & 0.3 & 0.1 & 0.1 & 2.0 & 5.1 & 2.0 & 2.7 \\
\hline Eggs & - & - & - & - & 4.1 & 1.3 & 0.1 & 0.4 \\
\hline \multicolumn{9}{|l|}{ Mollusca } \\
\hline Tellinidae & 0.0 & 0.2 & 0.0 & 0.0 & - & - & - & - \\
\hline Cardium spp. & 0.0 & 0.1 & 0.1 & 0.1 & - & - & - & - \\
\hline \multicolumn{9}{|l|}{ Polychates } \\
\hline Hediste diversicolor & 1.9 & 11.9 & 7.3 & 6.5 & 0.4 & 1.3 & 1.4 & 1.1 \\
\hline Vegetable & 0.1 & 1.1 & 0.1 & 0.3 & - & - & - & - \\
\hline
\end{tabular}

prey community $(N=58 \%$ and $B=73 \%)$. All other prey were of lesser importance (MFI $<25 \%$ ), although mysids occurred in $29 \%$ of the stomach contents. During these years (before Elymus invasion), there was no significant difference between the diets $\left(G_{\text {adj. }}=11.2, p>0.75\right)$.

In 2002 (after Elymus invasion), seven food items were identified in sea bass stomachs (Table 1); however, Neomysis integer was the most common (this mysid was present in $81 \%$ of stomachs containing food) and was the dominant prey $(\mathrm{MFI}=61 \%)$. Orchestia gammarella was now a secondary prey $(\mathrm{MFI}=32 \%)$ and was only present in $23 \%$ of sea bass stomachs. The other food items were scarcer (individual MFI $<3 \%$ ). These differences in sea bass diet were significant $\left(G_{\text {adj. }}=48.7, p<0.005\right)$ between 1997-1998 and 2002.

\subsection{Sand goby diet}

A total of 886 sand gobies (mean TF $\pm \mathrm{sd}=42.0 \pm 6.1 \mathrm{~mm}$, range between 20 and $69 \mathrm{~mm}$ ) were analysed in 1997; 184 sand gobies (mean TF $\pm \mathrm{sd}=40.5 \pm 7.2 \mathrm{~mm}$, range between 21 and $60 \mathrm{~mm}$ ) were caught and analysed in 2002. Pomatoschistus minutus diet composition followed the same trend noted for sea bass diet. In fact, $24 \%$ of sand gobies caught in 2002 had empty stomachs, whereas only $13 \%$ in 1997 . Differences of vacuity index were significant before (1997) and after (2002) Elymus invasion $\left(\chi^{2}=103.73, p<0.0001\right)$. 
Among the 13 food items identified in sand goby stomachs in 1997, Orchestia gammarella dominated $(N=72 \%$ and $B=76 \%$ ) and occurred in $72 \%$ of individual diets (Table 2). Eight food items were identified in 2002. Hediste diversicolor was the main food item $(\mathrm{MFI}=56 \%$ ), whereas $O$. gammarella and Neomysis integer were secondary (MFI $=18 \%$ and $11 \%$, respectively). These differences in sand goby diet were very significant $\left(G_{\mathrm{adj}}=51.3, p<0.005\right)$.

\subsection{Orchestia gammarella availabilities and accessibilities}

The amphipod Orchestia gammarella availabilities (Fig. 2) were significantly different (unpaired $t$ test with Welch correction, Welch's approximate $t=3.567, p=0.004$ ) between areas dominated by Atriplex portulacoides (mean $\pm \mathrm{sd}=650 \pm 456$ O. gammarella per $\mathrm{m}^{2}$; range: 229-1786) and areas dominated by Elymus athericus (mean $\pm \mathrm{sd}=171 \pm 92$ O. gammarella per $\mathrm{m}^{2}$; range: $\left.42-355\right)$. Accessibilities followed the same trend (Fig. 3), because $O$. gammarella was significantly more abundant (Welch's approximate $t=3.218, p=0.008$ ) in natural areas (i.e. A. portulacoides community) than in invaded areas (i.e. E. athericus community), mean $\pm \mathrm{sd}=1260 \pm 1139$ O. gammarella per day and per trap (range: 146-4287) and mean $\pm \mathrm{sd}=190 \pm 170$ O. gammarella per day and per trap (range: $31-472$ ), respectively.

\subsection{Vegetation height and litter depth}

The Community dominated by Atriplex portulacoides and the community dominated by Elymus athericus were significantly

Table 2

Food items identified in the stomach contents of sand goby caught during ebb in 1997 and in 2002. $N$ : numeric frequency. $B$ : biomass frequency. $F$ : frequency of occurrence. MFI: main food index

\begin{tabular}{|c|c|c|c|c|c|c|c|c|}
\hline & \multicolumn{4}{|l|}{1997} & \multicolumn{4}{|l|}{2002} \\
\hline & $N$ & $F$ & $B$ & MFI & $N$ & $F$ & $B$ & MFI \\
\hline \multicolumn{9}{|l|}{ Fishes } \\
\hline Clupeidae & - & - & - & - & 0.8 & 2.3 & 3.6 & 2.6 \\
\hline Pleuronectes platessa & 0.0 & 0.1 & 0.1 & 0.1 & - & - & - & - \\
\hline Pomatoschistus sp. & 0.4 & 1.6 & 1.3 & 1.0 & - & - & - & - \\
\hline \multicolumn{9}{|l|}{ Insects } \\
\hline Culicidae larvae & - & - & - & - & 20.6 & 9.2 & 0.3 & 2.4 \\
\hline Arachnids & 0.1 & 0.3 & 0.1 & 0.1 & - & - & - & - \\
\hline \multicolumn{9}{|l|}{ Crustacean } \\
\hline Palaemonetes varians & 0.1 & 0.4 & 0.6 & 0.4 & - & - & - & - \\
\hline Orchestia gammarellus & 71.9 & 71.8 & 75.7 & 72.9 & 9.6 & 26.2 & 14.9 & 18.3 \\
\hline Corophium volutator & 0.8 & 2.1 & 0.2 & 0.6 & - & - & - & - \\
\hline Sphaeroma rugicauda & 0.1 & 0.4 & 0.4 & 0.3 & - & - & - & - \\
\hline Eurydice pulchra & 2.8 & 7.2 & 1.1 & 2.3 & - & - & - & - \\
\hline Neomysis integer & 11.4 & 20.9 & 5.9 & 9.7 & 6.7 & 14.6 & 8.3 & 10.6 \\
\hline Copepodites & 9.3 & 3.6 & 1.3 & 2.9 & 13.5 & 6.9 & 0.4 & 2.3 \\
\hline Undetermined & 0.7 & 2.7 & 0.3 & 0.7 & 2.5 & 10.0 & 2.7 & 4.6 \\
\hline Eggs & - & - & - & - & 28.3 & 11.5 & 0.4 & 3.3 \\
\hline \multicolumn{9}{|l|}{ Polychates } \\
\hline Hediste diversicolor & 2.5 & 10.7 & 13.1 & 9.2 & 17.9 & 53.8 & 69.3 & 55.8 \\
\hline Vegetable & 0.0 & 0.1 & 0.1 & 0.1 & - & - & - & - \\
\hline
\end{tabular}

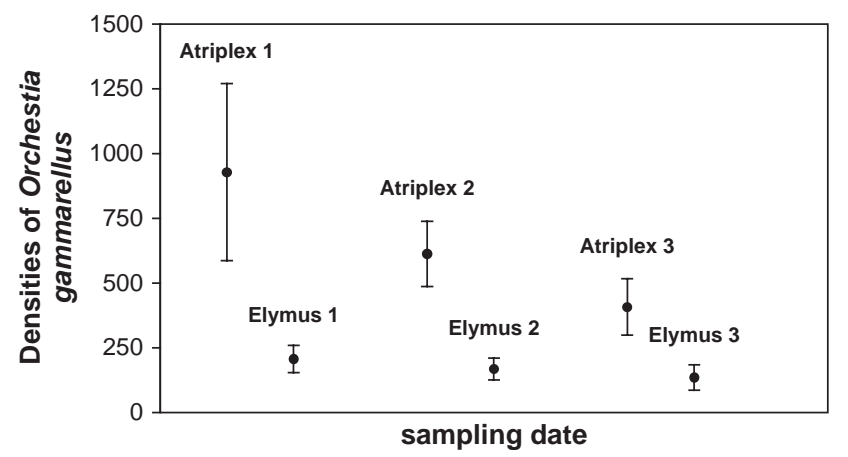

Fig. 2. Densities (number of individuals $\mathrm{m}^{-2}$ ) of Orchestia gammarella in invaded (Elymus athericus) and natural (Atriplex portulacoides) habitats (mean $\pm \mathrm{sd}, N=4$ per date).

different in terms of their vegetation height and litter depth (Welch's approximate $t=7.095$ and 8.124 , both $p<0.0001$, respectively). The community dominated by $A$. portulacoides was shorter (mean vegetation height $\pm \mathrm{sd}=25.4 \pm 5.8 \mathrm{~cm}$ ) than that of E. athericus $(65.4 \pm 18.6 \mathrm{~cm})$ and provided smaller amounts of litter (mean litter depth $\pm \mathrm{sd}=0.5 \pm 0.3 \mathrm{~cm}$ and $3.5 \pm 1.2 \mathrm{~cm}$, respectively, for $A$. portulacoides and for E. athericus).

\section{Discussion}

The Atriplex portulacoides and Elymus athericus communities are highly productive, generating a large quantity of organic matter (Lefeuvre et al., 2000) that can provide habitat and food for dense communities of marsh dwelling detritivorous crustaceans such as Orchestia gammarella (Créach et al., 1997). However, both availabilities and accessibilities of $O$. gamarella were significantly lower in invaded habitats than in natural habitats. Although these populations are likely to vary during a year and between years (Aksissou and Elkaim, 1994), the comparison of this food resource between natural and invaded areas is representative of a general decrease in population dynamics in invaded habitats (also analysed by the relative abundance of age classes: Pétillon et al., unpublished data). This trend can be related to a lower quality of food for this decomposer (presence of phytoliths and high

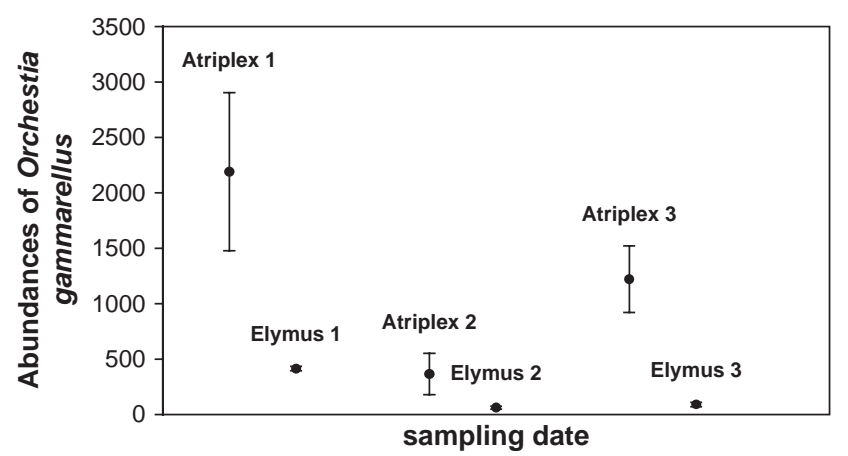

Fig. 3. Abundances (number of individuals $\mathrm{m}^{-2}$ ) of Orchestia gammarella in invaded (Elymus athericus) and natural (Atriplex portulacoides) habitats (mean $\pm \mathrm{sd}, N=4$ per date). 
lignin content: Valéry et al., 2004), which prefers to feed upon soft food items (Moore and Francis, 1985). The reduction in total densities of $O$. gammarella is, however, not enough to explain such a decrease of this food resource for sea bass and sand goby in invaded salt marshes by E. athericus. In fact, it can be argued that $O$. gammarella was very dense compared to other food resources in both natural and invaded sites, and therefore still available for fish even in the E. athericus community.

Furthermore, this amphipod is known to be greatly consumed in the Atriplex portulacoides community by Pomatoschistus minutus (Laffaille et al., 1999) and Dicentrarchus labrax (Laffaille et al., 2001). The decrease of the amphipod as food would therefore appear to be related to lower prey accessibility for fish in the Elymus athericus community than in A. portulacoides. One hypothesis is that the high quantity of litter produced by the tall grass $E$. athericus reduces Orchestia gammarella accessibility for fish communities. An increase of habitat complexity has already been proved to reduce foraging efficiency (e.g. Corona et al., 2000; Bush and Holland, 2002). Thus, Elymus invasion may be responsible for a reduction of both availability and accessibility of the main item $O$. gammarella, leading to a shift in food resources from this main item to the marine mysid Neomysis integer for sea bass and to the polychaete Hediste diversicolor for sand goby.

Orchestia gammarella is a semi-terrestrial crustacean with poor swimming capabilities. By comparison, the other invertebrates are more difficult to catch for aquatic predators either because they are better swimmers (e.g. Neomysis integer) or benthic invertebrates strongly associated with the substratum (e.g. Hediste diversicolor). It can be suggested that fish caught these difficult "substitution prey" mainly because they occur at very high densities in salt marsh creeks (see Holland et al., 2004 for polychaetes' density calculations), representing the main food item for other young fish species (e.g. N. integer for stickleback: Søndergaard et al., 2000). Feeding activity varied mainly according to the dominant vegetation, and sand gobies and young sea bass appeared to have an opportunistic feeding behaviour response to the invasion of Elymus athericus in the salt marshes. Such a shift due to a decrease of the main food item was already shown in sheep grazed salt marshes of the Mont-Saint-Michel Bay by Laffaille et al. (2000b). Once more, the semi-terrestrial O. gamarella was replaced by $N$. integer in sea bass diets.

Elymus invasion also resulted in lower food consumption (increase in vacuity index after Elymus athericus invasion) observed in Pomatoschistus minutus and Dicentrarchus labrax and supported by the non-significant difference between 1997 and 1998 (before Elymus invasion) for sea bass. The fact that diets of fish from uninvaded marsh were similar in 1997 and 1998 suggests, but clearly does not prove, that they would have been similar in 2002. But, differences between before and after Elymus invasion were great and certainly greater than between 1997-1998 and 2002 in an uninvaded marsh that does not now exist.

Elymus athericus invasion is thus likely to reduce the unique land-sea exchanges of organic matter via the fish vector. In fact, only a few fish species are able to assimilate salt marsh primary production directly or indirectly; this is the case for mullets Liza and Mugil spp., sand gobies Pomatoschisus spp. and sea bass Dicentrarchus labrax in the MontSaint-Michel Bay (Laffaille et al., 1998, 2002). Salt marsh primary production is essentially assimilated by many invertebrates, and especially by Orchestia gammarella and mysids in European salt marshes (Zagursky and Feller, 1985; Créach et al., 1997). Tidal creeks seem to act as a drainage area where the secondary production (i.e. invertebrates) of the whole salt marsh system gets concentrated. A previous study on the exploitation of the macrotidal salt marshes by the most abundant fish species (Laffaille et al., 2000a), confirmed the general assumption that nekton migrate into intertidal creeks and vegetated intertidal areas during flood tide to feed. Fish exploit this secondary production (i.e. invertebrates) and, indirectly, the large primary production of the macrotidal salt marshes during spring tides when vegetated intertidal surface is accessible. Following Elymus invasion, the primary production of invaded marsh areas is very high and similar to natural areas (Valéry et al., 2004). The reduction in secondary production export (mainly Amphipoda) by fishes could then lead to: (1) an accumulation of organic matter stocks in invaded salt marshes associated with very large quantities of litter (Valéry et al., 2004; present study) and (2) a disappearance of salt marsh trophic and nursery functions in the long term. Even if the trophic function of creeks in invaded systems is reduced, it is probable that young fishes will still frequent them because of their refuge function (e.g. Bush and Holland, 2002; Paterson and Whitfield, 2003).

The invasion pattern of Elymus athericus (Valéry et al., 2004) is similar to the invasion of Phragmites australis (common reed) in salt marshes along the North American Atlantic coast (see for example Bart and Hartman, 2000). In fact, $P$. australis in North American salt marshes has changed recently from a species with a limited distribution to an invasive species producing dense monospecific stands. This expansion has converted mosaics of vegetation into dense monotypic stands (Chambers et al., 1999), potentially changing the functions of these ecosystems. Some research has focused on whether $P$. australis stands to serve as a valuable wetland habitat and foraging areas for marsh nekton (Hanson et al., 2002). Moreover, there is evidence supporting the view that $P$. australis does not have a deleterious effect on the ability of marshes to function as habitat for fauna and especially nekton. Fell et al. (1998) and Warren et al. (2001) reported that fish foraging and the abundance of invertebrates were not affected by the expansion of $P$. australis. Other authors have found that fish species composition was also not affected by common reed invasion (Meyer et al., 2001) or that nekton densities are similar to those in some non- $P$. australis dominated wetlands (Hanson et al., 2002). Moreover, Wainright et al. (2000) provided evidence that $P$. australis may contribute to the food chain in tidal marsh systems. Other studies showed differences, such as Posey et al. (2003), who reported a slightly higher abundance of fauna in Spartina alterniflora marshes than in $P$. australis marshes. The reasons for these differences 
included the presence of shallow pools around $S$. alterniflora and the lack of them around $P$. australis, possible differences in food availability and differences in stem density and/or canopy thickness (Fell et al., 2003).

Increasing human pressure and activities have led to strong disturbances, functional changes and destruction of habitats, especially in wetland ecosystems (Lefeuvre et al., 2003). Throughout the world, most wetlands are exploited for agricultural purposes. One of the most common is the exploitation of the primary production by domestic stock grazing (Bakker, 1989). The impacts of herbivores on salt marshes-estuarine coastal systems are quite well known (Kiehl et al., 1996; Laffaille et al., 2000b; Lefeuvre et al., 2000). However, one recent and important impact on coastal wetland is that of invasive plants such as Elymus athericus (Bockelmann and Neuhaus, 1999) and Spartina spp. (Callaway and Josselyn, 1992). Similar to the spread of other invasive species, such as Lythrum salicaria (Mal et al., 1997) in freshwater wetlands, E. athericus (in Europe) and Phragmites australis (in North America) in coastal wetlands, invasive species tend to reduce species richness. In the case of Elymus, invaded habitats tend to present higher densities and species richness of terrestrial arthropods than natural habitats (Pétillon et al., 2005), except for amphipods (present study). The massive loss of species and ecosystems, and especially wetlands and associated organisms (Gibbs, 2000), has made it imperative to investigate the roles of species in the functioning of ecosystems (Schwartz et al., 2000) and more generally shifts in ecosystem functioning provoked by many invasive species. The conservation implications of the link between species richness and ecosystem function have recently been intensified (Hector et al., 2001) and management of invasive species is an urgent problem in conservation biology. In particular, it has been emphasized that invasions by E. athericus remain limited in salt marshes that are grazed by sheep (Bakker, 1989; Kiehl et al., 1996; Bouchard et al., 2003).

Following the Elymus athericus invasion, the tidal salt marsh of the Mont-Saint-Michel Bay seems to have changed its trajectory and now fulfils a new function: initially a source of organic matter, it might become a carbon sink (Valéry et al., 2004). In the long term, this $\mathrm{C}$ sequestration is likely to impact the marine food webs by reducing available resources, especially for fish species. This study shows that $E$. athericus invasion alters the trophic function for European fish and consequently the nursery function according to the definition of Beck et al. (2001). Bioenergetics and isotopic studies should urgently be conducted to determine the new trophic pathways leading to dominant fish production and the effects of the shift in dominant prey resources on trophic transfer dynamics.

\section{Acknowledgements}

We thank M. Ar Gouilh, A. Jan and C. Aubert for help in counting and identifying amphipods. This study was funded by: (1) the CNRS Program 'Environnement, Vie et Sociétés: Zone Atelier de la Baie du Mont-Saint-Michel et ses Bassins Versants', (2) Ministère de l'Ecologie et du Développement Durable Program
'Invasions Biologiques' and (3) Institut Français de la Biodiversité Program 'Usages et Biodiversités dans les Marais Salés'. We thank the reviewers for many helpful suggestions.

\section{References}

Able, K.W., Hagan, S.M., 2000. Effects of common reed (Phragmites australis) invasion on marsh surface macrofauna: response of fishes and decapod crustaceans. Estuaries 23, 633-646.

Aksissou, M., Elkaim, B., 1994. Biodémographie et dynamique d'une population d'Orchestia gammarellus (Crustacea, Amphipoda, Talitridae) du littoral méditerranéen du Maroc. Acta Ecologica 15, 633-659.

Bakker, J.P., 1989. Nature management by grazing and cutting. In: Geobotany, vol. 14. Kluwer Academic Publisher, Dordrecht, 400 pp.

Bart, D.J., Hartman, J.M., 2000. Environmental determinants of Phragmites australis expansion in a New Jersey salt marsh: an experimental approach. Oikos 89, 59-69.

Beck, M.W., Heck Jr., K.L., Able, K.W., Childers, D.L., Eggleston, D.B., Gillanders, B.M., Halpern, B., Hays, C.G., Hoshino, K., Minello, T.J., Orth, R.J., Sheridan, P.F., Weinstein, M.P., 2001. The identification, conservation, and management of estuarine and marine nurseries for fish and invertebrates. Bioscience 51, 633-641.

Bockelmann, A.C., Neuhaus, R., 1999. Competitive exclusion of Elymus athericus from a high-stress habitat in a European saltmarsh. Journal of Ecology $87,503-513$.

Boesch, D.F., Turner, R.E., 1984. Dependence of fishery species on salt marshes: the role of food and refuge. Estuaries 7, 460-468.

Bouchard, V., Digaire, F., Lefeuvre, J.-C., Guillon, L.M., 1995. Progression des marais salés à l'ouest du Mont-Saint-Michel entre 1984 et 1994. Mappemonde 4, 28-34.

Bouchard, V., Tessier, M., Digaire, F., Vivier, J.P., Valéry, L., Gloaguen, J.C., Lefeuvre, J.C., 2003. Sheep grazing as management tool in Western European saltmarshes. Comptes Rendus Biologies 326, 148-157.

Bush, A., Holland, K., 2002. Food limitation in a nursery area: estimates of daily ration in juvenile scalloped hammerheads, Sphyrna lewini (Griffith and Smith, 1834) in Kāne'ohe Bay, Ō' ahu, Hawai'i. Journal of Experimental Marine Biology and Ecology 278, 157-178.

Callaway, J.C., Josselyn, M.N., 1992. The introduction and spread of smooth cordgrass (Spartina alterniflora) in south San Francisco Bay. Estuaries 15, $218-226$.

Chambers, R.M., Meyerson, L.A., Saltonstall, K., 1999. Expansion of Phragmites australis into tidal wetlands of North America. Aquatic Botany 64, 261-274.

Corona, A., Soto, L.A., Sánchez, A.J., 2000. Epibenthic amphipod abundance and predation efficiency of the pink shrimp Farfantepenaeus duorarum (Burkenroad, 1939) in habitats with different physical complexity in a tropical estuarine system. Journal of Experimental Marine Biology and Ecology 253, 33-48.

Costa, M.J., Cabral, H.N., 1999. Changes in the Tagus nursery function for commercial fish species: some perspectives for management. Aquatic Ecology 33, 287-292.

Créach, V., Schricke, M.T., Bertru, G., Mariotti, A., 1997. Stable isotopes and gut analyses to determine feeding relationships in saltmarsh macroconsumers. Estuarine, Coastal and Shelf Science 44, 599-611.

Cronk, Q.C.B., Fuller, J.L., 2001. Plant Invaders: The Threat to Natural Ecosystems. Earthscan Publications, London, 255 pp.

Fell, P.E., Weissbach, S.P., Jones, D.A., Fallon, M.A., Zeppieri, J.A., Faison, E.K., Lennon, K.A., Newberry, K.J., Reddington, L.K., 1998. Does invasion of oligohaline tidal marshes by reed grass, Phragmites australis (Cav.) Trin. ex Steud., affect the availability of prey resources for the mummichog, Fundulus heteroclitus. Journal of Experimental Marine Biology and Ecology 222, 59-77.

Fell, P.E., Warren, R.S., Light, J.K., Rawson Jr., R.L., Fairley, S.M., 2003. Comparison of fish and macroinvertebrate use of Typha angustifolia, Phragmites australis, and treated Phragmites marshes along the lower Connecticut River. Estuaries 26, 534-551. 
Gibbs, J.P., 2000. Wetland loss and biodiversity conservation. Conservation Biology 14, 314-317.

Greenslade, P.J.M., 1964. Pitfall trapping as a method for studying populations of Carabidae (Coleoptera). Journal of Animal Ecology 33, 301-310.

Hamerlynck, O., Cattrijsse, A., 1994. The food of Pomatoschistus minutus (Pisces, Gobiidae) in Belgian coastal waters, and a comparison with the food of its potential competitor P. lozanoi. Journal of Fish Biology 44, 753-771.

Hanson, S.R., Osgood, D.T., Yozzo, D.J., 2002. Nekton use of a Phragmites australis marsh on the Hudson river, New York, USA. Wetlands 22, 326-337.

Hector, A., Joshi, J., Lawler, S.P., Spehn, E.M., Wilby, A., 2001. Conservation implications of the link between biodiversity and ecosystem functioning. Oecologia 129, 624-628.

Holland, A.F., Sanger, D.M., Gawle, C.P., Lerberg, S.B., Santiago, M.S., Riekerk, G.H.M., Zimmerman, L.E., Scott, G.I., 2004. Linkages between tidal creeks ecosystems and the landscape and demographic attributes of their watersheds. Journal of Experimental Marine Biology and Ecology 298, 151-178

Hooper, D.U., Vitousek, P.M., 1997. The effects of plant composition and diversity on ecosystem processes. Science 277, 1302-1305.

Kiehl, K., Eischeid, I., Gettner, S., Walter, J., 1996. Impact of different sheep grazing intensities on saltmarshes in northern Germany. Journal of Vegetation Sciences 7, 99-106.

Kourtev, P.S., Ehrenfeld, J.G., Haggblom, M., 2002. Exotic plant species alter the microbial community structure and function in the soil. Ecology 83 , $3152-3166$.

Kurata, K., Minami, H., Kikuchi, E., 2001. Stable isotope analysis of food sources for salt marsh snails. Marine Ecology and Progress Series 223, 167-177.

Laffaille, P., Brosse, S., Feunteun, E., Baisez, A., Lefeuvre, J.-C., 1998. Role of fish communities in particulate organic matter fluxes between salt marshes and coastal marine waters in the Mont-Saint-Michel bay. Hydrobiologia 373/374, 121-133.

Laffaille, P., Feunteun, E., Lefeuvre, J.-C., 1999. Compétition alimentaire entre deux espèces de gobies, Pomatoschistus lozanoi (de Buen) et $P$. minutus (Pallas), dans un marais salé macrotidal. Comptes Rendus de l'Académie des Sciences III-Vie 322, 897-906.

Laffaille, P., Feunteun, E., Lefeuvre, J.-C., 2000a. Composition of fish communities in a European macrotidal salt marshe (the Mont-Saint-Michel Bay, France). Estuarine, Coastal and Shelf Sciences 51, 429-438.

Laffaille, P., Lefeuvre, J.-C., Feunteun, E., 2000b. Impact of sheep grazing on juvenile sea bass, Dicentrarchus labrax L., in tidal salt marshes. Biological Conservation 96, 271-277.

Laffaille, P., Lefeuvre, J.-C., Schricke, M.T., Feunteun, E., 2001. Feeding ecology of 0-group sea bass Dicentrarchus labrax in salt marshes of MontSaint-Michel bay (France). Estuaries 24, 116-125.

Laffaille, P., Feunteun, E., Lefebvre, C., Radureau, A., Sagan, G., Lefeuvre, J.-C., 2002. Can thin-lipped mullet directly exploit the primary and detritic production of European macrotidal salt marshes? Estuarine, Coastal and Shelf Science 54, 729-736.

Laffaille, P., Baisez, A., Rigaud, C., Feunteun, E., 2004. Habitat preferences of different European eel size classes in a reclaimed marsh: a contribution to species and ecosystem conservation. Wetlands 24, 642-651.

Lefeuvre, J.-C., Bouchard, V., Feunteun, E., Grare, S., Laffaille, P., Radureau, A., 2000. European salt marshes diversity and functioning: the case study of the Mont-Saint-Michel bay, France. Wetland Ecology and Management 8, 147-161.

Lefeuvre, J.-C., Laffaille, P., Feunteun, E., Bouchard, V., Radureau, A., 2003. Biodiversity in salt marshes: from patrimonial value to ecosystem functioning. The case study of the Mont-Saint-Michel bay. Comptes Rendus Biologie 326, 125-131.

Loneragan, N.R., Bunn, S.E., Kellaway, D.M., 1997. Seagrass and mangroves as carbon sources for food webs supporting penaeid prawns in a tropical Australian estuary: a stable isotope study. Marine Biology 130, 289-300.

Mal, T.K., Lovett-Doust, J., Lovett-Doust, L., 1997. Time-dependant competitive displacement of Typha angustifolia by Lythrum salicaria. Oikos 79, 26-33.
Meyer, D.L., Johnson, J.M., Gill, J.W., 2001. Comparison of nekton use of Phragmites australis and Spartina alterniflora marshes in the Chesapeake Bay, USA. Marine Ecology Progress Series 209, 71-84.

Moore, P.G., Francis, C.H., 1985. Some observations on food and feeding of the supralittoral beach-hopper Orchestia gammarellus (Pallas) (Crustacea: Amphipoda). Ophelia 24, 183-197.

Moreira, F., Assis, C.A., Almeida, P.R., Costa, J.L., Costa, M.J., 1992. Trophic relationships in the community of the upper Tagus Estuary (Portugal): a preliminary approach. Estuarine, Coastal and Shelf Science 34, 617-623.

Naeem, S., Hakanson, K., Lawton, J.H., Crawley, M.J., Thompson, L.J., 1996. Biodiversity and plant productivity in a model assemblage of plant species. Oikos 76, 259-264.

Norris, K.J., Cook, T., O’Dowd, B., Durbin, C., 1997. The density of redshank Tringa totanus breeding on the saltmarshes of the Wash in relation to habitat and its grazing management. Journal of Applied Ecology 34, 999-1013.

Odum, E.P., 1968. Energy flow in ecosystems: a historical review. American Zoology 8, 11-18.

Paterson, A.W., Whitfield, A.K., 2003. The fishes associated with three associated intertidal salt marsh creeks in a temperate southern African estuary. Wetlands Ecology and Management 11, 305-315.

Posey, M.H., Alphin, T.D., Meyer, D.L., Johnson, J.M., 2003. Benthic communities of common reed Phragmites australis and marsh cordgrass Spartina alterniflora marshes in Chesapeake Bay. Marine Ecology Progress Series 261, 51-61.

Pétillon, J., Ysnel, F., Canard, A., Lefeuvre, J.-C., 2005. Impact of an invasive plant (Elymus athericus) on the conservation value of tidal salt marshes in western France and implications for management: responses of spider populations. Biological Conservation 126, 103-117.

Salgado, J.P., Cabral, H.N., Costa, M.J., 2004. Feeding ecology of the gobies Pomatoschistus minutus (Pallas, 1770) and Pomatoschistus microps (Kroyer, 1838) in the upper Tagus estuary, Portugal. Scientia Marina 68, 425-434.

Schwartz, M.W., Brigham, C.A., Hoeksema, J.D., Lyons, K.G., Mills, M.H., van Mantgem, P.J., 2000. Linking biodiversity to ecosystem function: implications for conservation ecology. Oecologia 122, 297-305.

Søndergaard, M., Jeppesen, E., Aaser, H.F., 2000. Neomysis integer in a shallow hypertrophic brackish lake: distribution and predation by three-spined stickleback (Gasterosteus aculeatus). Hydrobiologia 428, 151-159.

Tilman, D., Wedin, D., Knops, J., 1996. Productivity and sustainability influenced by biodiversity in grassland ecosystems. Nature 379, 718-720.

Valéry, L., Bouchard, V., Lefeuvre, J.-C., 2004. Impact of the invasive native species Elymus athericus on carbon pools in a salt marsh. Wetlands 24, 268-276.

Van Wijnen, H.J., Bakker, J.P., 1997. Nitrogen accumulation and plant species replacement in three salt marsh systems in the Wadden Sea. Journal of Coastal Conservation 3, 19-26.

Vitousek, P.M., Walker, L.R., Whiteaker, D., Mueller-Dombois, D., Matson, P.A., 1987. Biological invasion by Myrica faya alters ecosystem development in Hawaii. Science 238, 802-804.

Vitousek, P.M., 1990. Biological invasions and ecosystem processes: towards an integration of population biology and ecosystem studies. Oikos $57,7-13$.

Wainright, S.C., Weinstein, M.P., Able, K.W., Currin, C.A., 2000. Relative importance of benthic microalgae, phytoplankton, and the detritus of smooth cordgrass (Spartina) and the common reed (Phragmites) to brackish marsh food webs. Marine Ecology Progress Series 2000, 77-91.

Warren, R.S., Fell, P.E., Grimsby, J.L., Buck, E.L., Rilling, G.C., Fertik, R.A., 2001. Rates, patterns, and impacts of Phragmites australis expansion and effects of experimental Phragmites control on vegetation, macroinvertebrates, and fish within tidelands of the lower Connecticut River. Estuaries 24, 90-107.

Williams, D.A., 1976. Improved likelihood ratio tests for complete contingency tables. Biometrika 63, 33-37.

Zagursky, G., Feller, R.J., 1985. Macrophyte detritus in the winter diet of the estuarine mysid, Neomysis americana. Estuaries 8, 355-362. 